\author{
Maciej Perkowski \\ University of Bialystok
}

Ewelina Gruszewska

University of Bialystok

\title{
INTERPRETATION OF BILATERAL TREATIES FOR THE PROMOTION AND PROTECTION OF FOREIGN INVESTMENTS
}

\begin{abstract}
The issues discussed in the following article focus on legal regulations regarding bilateral interstate treaties for the promotion and protection of foreign investments (in the doctrine and the practice of international investment law commonly referred to as 'BITs', hereinafter referred to as 'BITs') that are made by nationals of one state in another state. Subject to this matter, contracting states agree to protect investors from the state party in the territory of their country and to arbitrate international investment disputes that might arise. Taking this into account the authors of this article would like to take up issues concerning bilateral investment treaties in the context of their interpretation. Both general problems regarding interpretation of bilateral investment treaties and specific rules of investment clauses' interpretation are taken into consideration. Simultaneously, in the last part of this paper, the authors briefly indicate rules for the interpretation made by the International Centre for Settlement of Investment Disputes (hereinafter referred to as 'ICSID'), an institution engaged in the settlement of investment disputes, mainly based on bilateral investment treaties. The specificity of the subject matter requires their thorough and accurate interpretation. Scientifically, it is important whether in relations between states situated on different stages of economic development, the interpretation confirms their inequality or rather this interpretation tries to restore such equality. In addition, the impact of regional legal regimes, binding for one contracting party, on the interpretation of BITs, appears to be meaningful. Due to the limited scope of this study, it is difficult to provide clear answers to these questions, however - given the on-going development of international cooperation and its interdependence - attempts to systematize the mere matter of bilateral treaties' interpretation, in the authors' opinion are worth studying.
\end{abstract}

\section{Development of Bilateral Investment Treaties}

Within the framework of deepening economic integration, international economic cooperation relates to the possibility of investing private investment in countries in which the investor does not have its registered office 
or place of residence. Before in the doctrine of public international law this issue was marginalized. ${ }^{1}$ Recently, there has been significant improvement in this respect, new appropriate monographs on the international investment law appeared. (Jeżewski, 2011). Failures in regulating comprehensively the status of foreign investment in the form of a multilateral convention was the result of general difficulties encountered in reaching a broader agreement on the principles of foreign investment protection. Despite this, the failure of the of international investment law development cannot be settled, which, however, is evolving constantly. ${ }^{2}$ Consequently, this is why prospecting for the international legal measures that were restricted subjectively and objectively was stimulated. The solution of the status quo are bilateral investment treaties concluded by states. These are agreements for the promotion and protection of foreign investments establishing the terms and conditions for private investment by nationals and companies of one state in another state. Based on the agreements, the investments made by foreign investors are treated fairly and on equally favourable conditions as business investment of national entrepreneur in host countries that are party to the treaty. The Vienna Convention on the Law of Treaties from the 23 of May $1969 \mathrm{r}$. - hereinafter referred to the Vienna Convention (United Nations Treaty Series, vol. 1155, p. 331), entered into force on 27 January 1980, defines a treaty as an international agreement concluded between States in written form and governed by international law, whether embodied in a single instrument or in two or more related instruments and whatever its particular designation. Currently multilateral international agreements are perceived as the main instruments governing international relations. Simultaneously, little attention is paid to playing vital role bilateral treaties that are concluded by individual countries, these are among other investment treaties. The first such kind of treaty was signed in 1959 between Germany and Pakistan. (Jeżewski, 2001, p. 98; Amerasinghe, 2008; Gaillard, 1999, (Eds.) Galicki, Kamiński \& Myszona-Kostrzewa, 2009, Hallward-Dreimeier, 2003; (Eds.) Muchlinski, P., Ortino F. \& Schreuer Ch., 2008, Schill, 2009; van Harten, 2007; Wyrozumska, 2006). Since the end of fifties there have been already over 2600 such kinds of agreements signed. Nearly $40 \%$ of those treaties contain specific clauses to ensure legal protection for the investors from "a sending country" in "a host country". These are very different specific detailed solutions; often even bilateral investment treaties formed by one state differentiate between each other (Piontek, 2009, p. 35 and next). Most BITs grant investments made by an investor of one Contracting State in the territory of the other, a number of guarantees, which typically lay down fair and equitable treatment, protection from expropriation, free transfer 
of means and full protection and security. The distinctive feature of many BITs is that they allow for an alternative dispute resolution mechanism, whereby an investor whose rights under the BIT have been violated could have recourse to international arbitration, often under the auspices of the International Centre for the Settlement of Investment Disputes, rather than suing the host State in its own courts (Wong, 2007, pp. 135-177). Poland has signed 61 such kind of bilateral agreements. (http://www.mg.gov.pl, accessed November 25, 2012).

Shortly after the conclusion of the first bilateral treaties for the promotion and protection of foreign investments, other European countries have introduced their own programs for the protection of foreign investments, together with developing countries, especially African countries, sometimes also Asian and Latin American. European countries usually before sending their investors prepared a model text of bilateral investment treaty, which was the starting point for negotiations with potential partners of an investment treaty. (Vandevelde, 2010, p. 5). Accordingly, BITs were similar in their structure, but under the influence of ensuing economic changes over recent years its model has evolved. What's more, the origin of developing canons is associated with the influence that was exerted by various draft conventions on the protection of foreign investment, which in turn resulted in the fact that the whole network of BITs was characterized, as a rule, by unique uniformity, although differences in their contents were noticeable due to divergences in the legal systems of common law and civil law and the nature of diverse languages. Most of BITs are concluded between highly developed and developing countries. On the other hand, two developing countries hardly ever conclude a bilateral investment treaty. However, bilateral treaties for the promotion and protection of foreign investments between two highly developed countries are rarely formed, because of greater confidence in the protection guaranteed to foreign investment under national law and the national judicial system. Currently, the network of BITs concluded by various countries is characterized by relative uniformity and consistency. They retain the structure of organized fundamental principles for the promotion and protection of foreign investments. (Vandevelde, 2010, pp. 6-10).

Ratio decidendi of concluding such contracts is to eliminate barriers to the free flow of private international investment, reduce the risk of foreign capital investment in the host countries and the constitution of specialized methods in order to protect investors' rights. Entrepreneurs, investing capital in a foreign country and facing economic barriers were basically helpless to ignorance of internal regulations. Therefore, the countries that were interested in inflow of foreign direct investment have decided to improve both, the 


\section{Maciej Perkowski, Ewelina Gruszewska}

situation of investors and their own economic situation. This is why agreements concluded with developed countries constituted a kind of a remedy to ensure the improvement of economic conditions based on the principle of the rule of law and ultima ratio the equal treatment. The value added of treaties for the promotion and protection of foreign investments depends on the will of the host countries, which are required to meet a number of legal obligations imposed on them by the treaties. Simultaneously, an encouragement and an incentive for host countries is the fact that the purpose of concluding BITs is to promote economic development through the creation of a more liberal system of international investment; precisely they aim at creating such favourable conditions in order to encourage foreign investors to invest in the market of the host country.

Bilateral treaties for the promotion and protection of foreign investments are international agreements governing pretty narrow subject matter of economic activity. So how should they be interpreted? Is it enough to apply general rules of international treaties interpretation based on the general theory of public international law? Are detailed rules for treaties' interpretation required because of their characteristics? Does the conceptual grid used in the agreements concluded by European countries have the same meaning as the one used by Asian countries, for instance in China? In the following article the authors try to answer the above-mentioned questions.

\section{The notion of foreign investment}

Deliberations on the interpretation of the bilateral treaties for the promotion and protection of foreign investments should start from the concept of foreign investment. Both statutory law and doctrine have not developed commonly accepted definition of foreign investment, yet. M. Sornarajah, the author of a comprehensive study on the foreign investment issue defines it as an undertaking on a foreign scale based on the transfer of tangible or intangible assets from one country to another to exploit them in the host country in order to produce wealth under full or partial control of the owner of the relevant assets. (Sornarajah, 2010, p. 10). The capital-exporting state adopts the obvious strategy of defining the foreign investment protected by the treaty to contain three principal concerns. These are, first, to protect the physical property of the foreign investors; second, to extend protection to the intangible rights, which are themselves to be regarded as property and to be protected as such; and, third, to include within foreign investment the administrative rights that are necessary for the operation of the investment 
project. The latter rights are granted by the state as intangible rights relating to most intellectual property. Technically, the state which gives can take back what it gives. But, the treaty has the effect of lifting out of the realm of domestic law the right that is given to the foreign investor and subjecting it to treaty protection so that the right cannot be withdrawn without engaging the responsibility of the state. However, the right that is given by the domestic law is subject to conditions created in that law, there cannot possibly be treaty violations where the right is withdrawn for violations of the conditions. (Sornarajah, 2010, p. 16). Quoted definition acknowledges the criteria of its absolute stability and having control by investors over transfer assets with the aim of reaping benefits. The statement phrased by Sornarajah and similar opinions (Graham, Krugman, 1995) are amply proved correct in practice. Also, it is confirmed by arrangements laid down in the Report of the United Nations Conference on Trade and Development (UNCTAD) on the legal status of foreign investment. ${ }^{3}$

Substantially, in the European Union free movement of capital is an essential element for the proper functioning of the large European internal market. Investors and suppliers of capital must be able to offer their resources on the market where there is the greatest interest. The $1988 \mathrm{Di}$ rective (Official Journal L 178, 08/07/1988) and the Agreement on the European Economic Area (Official Journal L 001, 03/01/1994) ensure the full liberalization of capital movements. Under this Directive, all restrictions on capital movements between persons (natural or legal) resident in Member States were removed in the beginning of the nineties. Monetary and quasimonetary operations (financial loans and credits, operations in current and deposit accounts and operations in securities and other instruments normally dealt in on the money market) in particular were liberalized. However, the provisions of the new European treaties go even further than the 1988 Directive in the liberalization of capital movements. The principle of the free movement of capital and payments is now expressly laid down in the Treaty on the functioning of the EU. Article 63 of the TFEU (Official Journal of the European Union C 83/47) declares, in fact, that all restrictions on the movement of capital between Member States and on payments between Member States and third countries are prohibited. It thus extends the liberalization of capital movement to and from third countries. Article 66 of the TFEU however, authorizes temporary safeguard measures to be taken where, in exceptional circumstances, movements of capital to or from third countries cause, or threaten to cause, serious difficulties for the operation of economic and monetary union. In addition, article 65 of the TFEU authorizes Member States to take all requisite measures to prevent infringements 
of national law and regulations, in particular in the field of taxation and the prudential supervision of financial institutions. (Moussis, 2011, pp. 85116). According to the Court of Justice, the free movement of capital is a fundamental principle of the Treaty on the functioning of the EU, which may be restricted only by national rules which are justified by overriding public-interest grounds and that national rules guarantee the attainment of the objective pursued and satisfy the criterion of proportionality. ${ }^{4}$

\section{General principles concerning the interpretation of bilateral treaties for the promotion and protection of foreign investments}

Bilateral treaties for the promotion and protection of foreign investments have, as a rule, similar structure and scope of application. Due to that fact, most legal theoreticians and practitioners perceive them as a legal standard applicable to the obligations of foreign investors. In fact, each of the treaty constitutes separate legal regulations; however, the scope of application of some bilateral investment treaties may be of great importance and significance for the interpretation of other contracts. ${ }^{5}$ Interpretation of bilateral investment with its entitling and obligating nature, although seemingly appears not to cause any problems, but in fact is not a simple matter. Since the practice of mutual application of the bilateral investment treaties does not stir up controversy, there are also no problems with their interpretation. However, when such controversies arise, the situation appears to be much more complicated, as the scale of the interpretation difficulties grows significantly comparing with the interpretation of multilateral agreements. While interpreting the latter, there are numerous frames of reference, such as the stands taken on this matter by other parties to the agreement in question or the depositary's opinion. When a dispute of the parties to bilateral investment treaty arises, it means that the parties will be thorougly involved. Then each argument that is put forward encounters a counter-argument. Certainly, substantive matter of BITs facilitates its interpretation. Since the terms of the mutual investment protection constitute an objective point of reference, the principles of international investment law and aims to protect the investor and the investment must be taken into account. International investment law has developed itself to such an extent that nowadays it has particular canons and legal models. ${ }^{6}$

Some countries, adopting an expansive investment policy, decided to draw up a model of investment treaties, which usually constitute only a starting point for further negotiations with the latter party to an agree- 
ment. These model laws show the general approach of the state to such treaties as well as facilitate their conclusion. These models are changing following changes of the investment policy of the state and the external legal trends. As an example it is worth pointing out the case of American investment policy. Until recently, the model from 1994 had the force of law, which could be described as very aggressive - promoting the protection of investors. This was due to the fact that at that time the U.S. primarily exported capital to other foreign countries. In 2004, The United States Department of Commerce drew up a new model, much more balanced and securing the fundamental interests of the state, which in turn was the result of changes in the structure of capital flows from and to the United States. Similar changes can be discerned in the Chinese policy, hence one can talk about the third or even the fourth generation of Chinese bilateral investment treaty model. A number of other states also publicly announced its model regulations, which can be regarded as a kind of basis for the determination of some trends in this area. It is worth indicating that Poland has not developed its own model of BIT, what in historical perspective should be evaluated negatively. However, given the current trends within the European Union focusing on reducing the competence of the Member States in subject area, this opinion loses some of its importance.

Interpretation of bilateral treaties for the promotion and protection of foreign investments is particularly significant in the process of their application. This procedure is far more complicated than the interpretation of domestic law. Texts of the agreements are often vague, simply not because of inaccurate editorial techniques, but conduct of the parties to the contract agreed-upon taking into consideration necessity for different interpretations. The starting point in the interpretation of the contracts in question are three most important issues concerning the problem of international treaties interpretation, namely the basis on which interpretation is done and who (the subjects) and how actually does the interpretation?

When answering this question one should start from the general rules of interpretation of international treaties rooted in public international law that form foundation of their interpretation. ${ }^{7}$ According to Article 31 of the Vienna Convention on the Law of Treaties "a treaty shall be interpreted in good faith in accordance with the ordinary meaning to be given to the terms of the treaty in their context and in the light of its object and purpose" (Article 31 (3) of the Vienna Convention, United Nations Treaty Series, vol. 1155, p. 331). It means that the Convention points out three main rules regarding a treaty's interpretation: in connection with pacta 
sunt servanda principle, a treaty shall be interpreted in good faith; a special meaning shall be given to a term if it is established that the parties so intended, and the meaning of particular terms of the treaty should be considered together with their context and in the light of its object and purpose. (Góralczyk, Sawicki, 2011, p. 95; Grzybowski, 2012, pp. 46-60, especially 50). "The context for the purpose of the interpretation of a treaty shall comprise, in addition to the text, including its preamble and annexes: any agreement relating to the treaty which was made between all the parties in connection with the conclusion of the treaty; any instrument which was made by one or more parties in connection with the conclusion of the treaty and accepted by the other parties as an instrument related to the treaty". (Article 31 (2) of the Vienna Convention, United Nations Treaty Series, vol. 1155, p. 331). Simultaneously, together with the context, there shall be taken into account "any subsequent agreement between the parties regarding the interpretation of the treaty or the application of its provisions; any subsequent practice in the application of the treaty which establishes the agreement of the parties regarding its interpretation; any relevant rules of international law applicable in the relations between the parties". (Article 31 (3) of the Vienna Convention, United Nations Treaty Series, vol. 1155 , p. 331$)$.

Regardless of the afore-mentioned differences, bilateral investment treaties are characterized by certain common features allowing for pointing a common denominator, and also treating them as being of the same kind of agreements. The essence of BITs is the purpose of their conclusion expressed in reciprocal encouragement to increase the flow of foreign investment, promotion and protection of investments in each other's territories by companies based in either country. The aim of the parties to an agreement is to make profits - financial profit by an investor and infrastructural by a host state, these are measured among others by the creation of workplaces and the economic development. Moreover, it is important to take into account the subject matter and characteristics of foreign investment and mutual protection and promotion (as it was described above). To all intents and purposes, most treaties define (for the purpose of each particular contract) the notions of an investment and an investor, sometimes adding definitions of other terms, such as "the flow of capital". BITs rarely normalize investors' obligations, except for the general obligation to respect the law of the host state, taking into consideration other standards directly connected with the protection of international investments. However, it is worth noting that modern models of bilateral investment treaties include such standards broadly. Above-mentioned was analysed by the Arbitrary 
Tribunal in the case of Vivendi versus the Republic of Argentina, where the Tribunal indicated three elements making up together a general rule of interpretation. Firstly, the principle of good faith is of the great importance. Secondly, linguistic interpretation cannot rely solely on semantic treatment based on determining the literal meaning of words. Thirdly, words should not be analysed in abstracto but in the context of the treaty and in the light of their object and purpose. ${ }^{8}$

Legal value of bilateral treaties for the promotion and protection of foreign investments also depends, to a large extent, on who interprets the contract. And here one should distinguish: the doctrinal interpretation carried out by theoreticians of public international law and the formal interpretation - carried out either by the parties themselves, or by international courts (judicial interpretation) or by organs of international organizations.

The doctrinal interpretation can only have an indirect effect on the interpretation adopted by the parties to the agreement or the officials and international courts. To follow with, the formal interpretation plays a crucial role. The main role is played by the so-called authentic interpretation, which is carried out jointly by the parties to the contract, or the quasi-authentic interpretation, resulting from the consistent conduct of states. However, such interpretations are extremely rare in practice. Interpretation is also of great importance at the stage of dispute resolution. Therefore, when there are differences in the understanding of the agreement, these issues are decided by judicial interpretation - by the International Court of Justice or by an arbitral tribunal (the arguable arbitration clause), and it is formally binding on the parties to the dispute. (Art. 59 of ICJ Statute, an integral part of the UN Charter, available at the official website of International Court of Justice http://www.icj-cij.org, retrieved November 01, 2012). In the case of bilateral treaties for the promotion and protection of foreign investments, the interpretation put on by international organizations is of great importance, namely the International Centre for Settlement of Investment Disputes (as expanded later in this article).

In a situation where the above-mentioned types of interpretation leave ambiguity and when by usual means one cannot reach a reasonable and consistent results, then the auxiliary means of interpretation are used, including travaux préparatoires ${ }^{9}$ of an agreement and the circumstances in which it was concluded.

Furthermore, bilateral treaties for the promotion and protection of foreign investments usually include framework clauses, these are typical sub- 
stantive standards expressed in treaties. They contain objective and relative standards. These are as follows:

- most-favoured-nation treatment,

- national treatment,

- fair and equitable treatment,

- protection and security standard,

- guarantees of free transfers of funds,

- compensation in the event of expropriation or damage to the investment,

- dispute settlement mechanisms, both state-state and investor-state. ${ }^{10}$

\section{Interpretation of treaties' clauses in general outline}

From the economic point of view, concluding investment agreements does not directly affect the increase in the inflow of foreign investment to countries that enter into a contract. (Hallward-Dreimeier, 2003).

Significance should be attached substantially to investments conditions set unilaterally by the host country, such as tax-related initiatives, special privileges and the potential for development of the particular sector of the economy. However, bilateral investment treaties constitute a kind of an insurance policy in a broad sense that allows the investor to eliminate at least part of the risk associated for instance with seizing power by a new government which might influence changeable investment conditions. Therefore, models of bilateral treaties for the promotion and protection of foreign investment assure the confidence in the country, as well as provide a stable balance between the rights of the investor and the states - parties to a treaty. In the following paper the authors concentrate on the clauses that affect BITs interpretation the most.

The first type of the above-mentioned canons are relative standards, which are typical elements of the treaties in the field of international investment law relating to the treatment of other entities. The analysis of these standards should begin with deliberation of most-favoured-nation treatment clause (hereinafter referred to MFN treatment), which in the context of investment ensures that a host country extends to the covered foreign investor and its investments, as applicable, treatment that is no less favourable than that which it accords to foreign investors of any third country. ${ }^{11}$ While MFN is a standard of treatment which has been linked by some to the principle of the equality of States, the prevailing view is that a MFN obligation exists only when a treaty clause creates it. ${ }^{12}$ In the absence of a treaty obligation (or for that matter, an MFN obligation under national law), nations retain 
the possibility of discriminating between foreign nations in their economic affairs. (Most-Favoured-Nation Treatment in International Investment Law, Organization for Economic Co-operation and Development's working papers on international investment, 2004/2). The MFN treatment is defined by the Draft articles on MFN as the: "[...] treatment accorded by the granting State to the beneficiary State, or to persons or things in a determined relationship with that State, not less favourable that treatment extended by the granting State to a third State or to persons or things in the same relationship with that third State" (Article 5 of the Draft Articles on MostFavoured-Nation Clauses, (Yearbook of the International Law Commission, 1978, Vol. II, Part Two, p. 21)).13 And an MFN clause as: “...a treaty provision whereby a State undertakes an obligation towards another State to accord most-favoured treatment in an agreed sphere of relations". (Article 4 of the Draft Articles on Most-Favoured-Nation Treatment). In the context of international investment, in early BITs, the inclusion of MFN treatment clauses was generalized in order to ensure that the host States, while not granting national treatment (hereinafter referred to $N T$ ), would accord a covered foreign investor a treatment that is no less favourable than that it accords to a third foreign investor and would benefit from NT as soon as the country would grant it. Nowadays the overwhelming majority of international investment agreements have a MFN provision that goes alongside NT, mostly in a single provision. (Most-Favoured-Nation Treatment, UNCTAD Series on Issues in International Investment Agreements II, United Nations, New York and Geneva, 2010, p. 13). The MFN treatment provision has some main legal features. Firstly, it is a treatybased obligation that must be contained in a specific treaty and it requires a comparison between the treatment afforded to two foreign investors in like circumstances. It is therefore, a relative standard and must be applied to similar objective situations. Simultaneously, an MFN clause is governed by the eiusdem generis principle (Kałduński, 2006, p. 177), in that it may only apply to issues belonging to the same subject matter or the same category of subjects to which the clause relates. The MFN treatment operates without prejudice to the freedom of contract and thus, States have no obligation under the MFN treatment clause to grant special privileges or incentives granted through a contract to an individual investor or to other foreign investors. In order to establish a violation of MFN treatment, a less favourable treatment must be found, based on or originating from the nationality of the foreign investor. In the context of its purposes international trade, MFN treatment is essential for ensuring a level playing field between all trading partners and is therefore the central pillar of 


\section{Maciej Perkowski, Ewelina Gruszewska}

the international trading system. Likewise, MFN treatment in investment treaties is meant to ensure equality of competitive conditions between foreign investors of different nationalities seeking to set up an investment or operating that investment in a host country. Foreign investors seek sufficient assurance that there will not be adverse discrimination which would put them at a competitive disadvantage. Such discrimination includes situations in which competitors from other foreign countries receive more favourable treatment. The MFN standard thus helps to establish equality of competitive opportunities between investors from different foreign countries. It prevents competition between investors from being distorted by discrimination based on nationality considerations. The scope of application of an MFN treatment clause needs to be considered both in its subjectmatter coverage and in its substantive coverage. Substantive coverage is generally established by the text itself by defining the covered beneficiaries, the covered phases of investment and any applicable exceptions. More specifically, the scope of application of the clause and its interpretation will depend on whether MFN treatment covers: investors; or/and their investments and whether it covers: the post-establishment phase; or both the pre/post-establishment phases. Moreover, this basic construction may include: generic exceptions; or/and country-specific exceptions. Furthermore, the MFN treatment clause may include specific qualification or clarification in order to provide certainty and guidance so as to facilitate its interpretation and application as intended by the contracting parties. (Most-FavouredNation Treatment, UNCTAD Series on Issues in International Investment Agreements II, United Nations, New York and Geneva, 2010, p. 13-14). The application of MFN treatment in international investment treaties has to be interpreted in the light of general principles of treaty interpretation. MFN treatment refers to material treatment in the economic sphere and concerns the rules that establish the competitive conditions and opportunities to foreign investors and their investments. By prohibiting differentiated treatment as regards the competitive framework, the MFN treatment clause establishes a level field amongst the relevant players and avoids market distortions, favouring a sound competitive environment, thus contributing to the economic objective of the international investment treaties. MFN treatment means subjecting all foreign investors to the same rules and operational and transactions costs they face in their regular activities, as well as offering them the same market access and operational conditions and opportunities. (Most-Favoured-Nation Treatment, UNCTAD Series on Issues in International Investment Agreements II, United Nations, New York and Geneva, 2010, p. 30-33). 
Another relative standard, which is worth discussing in the context of bilateral treaties' interpretation, is the national treatment clause, a concept of international law that declares if a state provides certain rights and privileges to its own nationals, it also should provide equivalent rights and privileges to foreigners who are currently in the country. (Bjorklund, 2008, p. 29). While this is generally viewed as a desirable principle, in custom it conversely means that a state can deprive foreigners of anything of which it deprives its own nationals. This concept of equality can be found in bilateral tax treaties and also it is an integral part of most World Trade Organization agreements. Together with the most-favoured-nation treatment principle, national treatment is one of the cornerstones of the WTO trade law. Article 3 of the General Agreement on Tariffs and Trade, shortly referred to as GATT, prohibits discrimination between imported and domestically produced goods with respect to internal taxation or other government regulation; article 17 of the General Agreement on Trade in Services, shortly referred to as GATS and art. 3 of the Agreement on Trade Related Aspects of Intellectual Property Rights, Including Trade in Counterfeit Goods, shortly referred to as TRIPS aims at the trade rule to prevent internal taxes or other regulations from being used as a substitute for tariff protection. (The World Trade agreements available online on its official website, from http://www.wto.org, retrieved November 28, 2012). It is important, as shown by R. Dolzer and Ch. Schreuer, as it is "generally recognized that the use of the clause depends on the actual state (...). This statement means that the standard is not subject to any abstract definitions and there is no single point of reference to its interpretation" (Dolzer, Schreuer, 2008, pp. 178-179, quotation from: Jeżewski, 2011, pp. 178-201). Therefore, any analysis of the national treatment standard requires firstly to determine the specific wording of the treaty clause and its interpretation in accordance with the provisions of the Vienna Convention on the Law of Treaties.

The above-discussed clauses have different scope of application, include both issues on the admission of investment in the territory of the contracting parties and limit national treatment only to investments already admitted. (Jeżewski, 2011, pp. 178-204).

The second type of clauses in the field of international investment law are objective standards, that are separate from the treatment of other entities. The first of these canons is the fair and equitable treatment standard (hereinafter referred to as FET) which is an absolute standard of protection. It applies to investments in a given situation without reference to how other investments or entities are treated by the host state. Thus, host gov- 


\section{Maciej Perkowski, Ewelina Gruszewska}

ernments are unable to resist a claim under this standard by saying that the treatment is no different from that experienced by their own nationals or other foreign investors operating in their economy. In relation to usage in BITs, the original purpose and intent behind FET clauses was to protect against the many types of situations of how unfairness may manifest itself, such as, for example, an arbitrary cancellation of licenses, harassment of an investor through unjustified fines and penalties or creating other hurdles with a view to disrupting a business. Here the standard would provide a gap-filling device, as not all kinds of unfair administrative or governmental conduct could be subsumed under the more specific non-discrimination or protection-of-property standards contained in BITs. (Dolzer, Schreuer, 2008, p. 122). Until the recent rise of arbitral interpretations of the FET standard, its meaning was not generally determined. The word fair is defined by the Concise Oxford Dictionary as "just, unbiased, equitable, in accordance with rules". Therefore, fairness connotes, among other things, equity. The concepts of fair and equitable are, to a large extent, interchangeable. In addition, equity suggests a balancing process, weighing up of what is right in all the circumstances. It is a word related to the idea of equilibrium defined as "a state of physical balance". The balancing function of equity is accepted as an aspect of international law. Thus, based on a plain meaning of the words, "fair and equitable" treatment requires an attitude to governance based on an unbiased set of rules that should be applied with a view to doing justice to all interested parties that may be affected by a State. ${ }^{14}$ Next, most bilateral investment treaties include provisions granting full protection and security for investments. The meaning of these clauses suggests that the host State is under an obligation to take active measures to protect the investment from adverse effects. (Cordero-Moss, 2008, p. 132). The adverse effects may stem from private parties or from actions of the host State and its organs. Recently tribunals have found that provisions of this type also guaranteed legal security enabling the investor to pursue its rights effectively. However, tribunals have disagreed on whether full protection and security merely reflects the broader, fair and equitable treatment standard and customary international law or offers an independent and additional standard. Arbitral practice has generally agreed that this standard of protection merely requires due diligence and does not create absolute liability. (Dolzer, Schreuer, 2008; Salacuse, 2010). Other specific provisions of a bilateral investment treaty guarantee free transfers of funds. It is of great importance for investors to assure the standard at every stage of making investments. Initially, it is essential to transfer the capital to the host country in order to start the investment. Then, this standard should aim at guaran- 
Interpretation of Bilateral Treaties for the Promotion and Protection...

teeing freedom of investment and its extensions. Then, the efficiency benefits of the investments required to be able to transfer profits and other benefits to the investor's home country. Finally, in the event of termination of investment, the investors should be able to transfer their capital back to their home country or any location of their choice. (Jeżewski, 2011, pp. 284-296; Salacuse, 2010; Schill, 2009).

Moreover, the doctrine of the investment also indicates other model standards - called 'indirect standards', these are among others the principle pacta sunt servanda and the prohibition of expropriation and measures.

\section{Interpretation of bilateral investment treaties put on by International Centre for Settlement of Investment Disputes}

According to art. 38 of the International Court of Justice Statute, ${ }^{15}$ sources of international law consist of international conventions, whether general or particular, establishing rules expressly recognized by the contesting states; international custom, as evidence of a general practice accepted as law and the general principles of law recognized by civilized nations. Judicial decisions and the teachings of the most highly qualified publicists of the various nations are subsidiary means for the determination of rules of law. Legal theory indicates that the interpretation of law must take into account the existence of legal institutions (however lawyers do not consistently use a well-defined notion of an international institution). Specific provisions should be interpreted in the context of legal institutions and interpretation should also take into consideration the objectives of the institutions and rules that govern them. In other words, lawyers deal with the legal provisions that should not be viewed in isolation, but as components of legal institutions. (Gizbert-Studnicki, 2011, p. 123). A slightly different opinion on this thesis is substantiated by legal practitioners. (Walencik, May 30, p. C4). International Centre for Settlement of Investment Disputes is an autonomous international institution established under the Convention on the Settlement of Investment Disputes between States and Nationals of Other States with over one hundred and forty member States. ${ }^{16}$ The primary purpose of ICSID is to provide facilities for conciliation and arbitration of international investment disputes. ${ }^{17}$ The Convention sought to remove major impediments to the free international flow of private investment posed by non-commercial risks and the absence of specialized international methods for investment dispute settlement. ICSID was created by the Convention as an impartial international forum providing facilities 
for the resolution of legal disputes between eligible parties, through conciliation or arbitration procedures. Recourse to the ICSID facilities is always subject to the parties' consent. The ICSID Convention requires the Centre to maintain a Panel of Conciliators and a Panel of Arbitrators. The Panels are an important component of the ICSID system of dispute settlement. When the Chairman of the Administrative Council is called upon to appoint conciliators, arbitrators or ad hoc Committee members under the ICSID Convention, these appointees must be drawn from the Panels. ${ }^{18}$ According to the art. 50 of the Convention on the Settlement of Investment Disputes between States and Nationals of Other States, if any dispute shall arise between the parties as to the meaning or scope of an award of ICSID, either party may request interpretation of the award by an application in writing addressed to the Secretary-General. The request shall, if possible, be submitted to the Tribunal which rendered the award. As evidenced by its large membership, considerable caseload, and by the numerous references to its arbitration facilities in investment treaties and laws, ICSID plays an important role in the field of economic development and international investment, including its interpretation. Today, ICSID is considered to be the leading international arbitration institution devoted to investor-State dispute settlement. ISCID tribunals arbitrate disputes arisen between investors and states, this is why they might face problems of interpretation in relation to the following issues: not only bilateral investment treaties but also the meaning of the provisions of the ICSID Convention, multilateral investment agreements, international customary law, general principles of international law or national legislation. (Jeżewski, 2011, pp. 14-19). Those tribunals apply interpretative arguments in determining the meaning of the rules applicable in particular cases. Among those per analogiam and a contrario arguments are two interpretive arguments used the most.

\section{Summary}

Contracting parties to bilateral investment treaties should not duplicate provisions of positive international law, but seek to establish uniform rules for treaties' interpretation as effective instruments for the promotion and protection of foreign investments in each other's territories by companies based in either country. Simultaneously, secondary improvement of the interpretation of bilateral investment treaties provides a constructive argument for the settlement of disputes between an investor and the host coun- 
try, which directly affects economic undertakings and so-called "economic climate". (For more information, see: Gilas (1998). Globalization introduces some chaos, however it requires very structured legal services.

\section{N O T E S}

${ }^{1}$ Discussions regarding these issues were held in various ways, for example (Gilas, 1998).

2 Interestingly this process was explained (Lachs, 1992, p. 17-24).

${ }^{3}$ For more information, see: (World Investment Report 2007, Transnational Corporations, Extractive Industries and Development, New York-Geneva 2007).

${ }^{4}$ Commission of the European Communities v. Italian Republic, Case C-174/04, from (http://eur-lex.europa.eu, retrieved November 27, 2012).

5 Compare: Asian Agricultural Products Ltd. Versus Republic of Sri Lanca, arbitration award from June 27, 1990, § 21, quotation from: (Jeżewski, 2011, p. 98).

6 Disquisition is based on the simplistic reasoning from (Bos, 1984, p. 105 and next; Kawaguchi, 2003, 53).

7 Systematized rules of interpretation are comprised in the Vienna Convention on the Law of Treaties, (United Nations Treaty Series, vol. 1155, p. 331, part III, section 3, Art. 31-33).

8 Suez, Sociedad General de Aguas de Barcelona S.A. and Vivendi Universal S.A. versus Argentine Republic, Decision on the Argentine Republic's Request for a Continued Stay of Enforcement of the Award rendered on August 20, 2007, ICSID Case No. ARB/03/19, $\S$ 7.4.3, from (https://icsid.worldbank.org, retrieved November 25, 2012).

9 Preparatory works constitute the materials used in preparing the ultimate form of an agreement or statute, especially of an international treaty. The materials constitute a legislative history. Travaux preparatoires contain the various documents including reports of discussions, hearings and floor debates that were produced during the drafting of a Convention, treaty or an agreement. Travaux preparatoires of a statute or treaty are usually recorded so that it can be used later in order to interpret that particular statute or treaty. This is a secondary form of interpretation and is used to clarify the intent of the makers of the statute or treaty. No reference should be made to travaux préparatoires, if the text of the agreement is sufficiently clear, as it has been confirmed by the jurisdiction of international courts.

10 The division adopted from United Nations Conference on Trade and Development. See also (Jeżewski, 2011, p. 141).

11 See (Most-Favoured-Nation Treatment, UNCTAD Series on Issues in International Investment Agreements II, United Nations, New York and Geneva, 2010, p. 13). See also: (Ziegler, 2008).

12 See Article 7 of the Draft Articles on Most-Favoured-Nation Clauses, the related comments and the doctrine here referred ((Eds.) Jennings, Watts, 1992, p. 1326).

13 Article 5 of the Draft Articles on Most-Favoured-Nation Clauses (ILC Draft), (Yearbook of the International Law Commission, 1978, Vol. II, Part Two, p. 21). It constitutes useful material for interpretative purposes.

${ }^{14}$ Fair and Equitable Treatment, (UNCTAD Series on Issues in International Investment Agreements II, New York and Geneva, 2012, p. 6-10). See also: (Jeżewski, 2011, pp. 205$216,267-284)$. 


\section{Maciej Perkowski, Ewelina Gruszewska}

15 International Court of Justice Statute, from (http://www.icjcij.org/documents/index. php?p1 $=4 \& \mathrm{p} 2=2 \& \mathrm{p} 3=0$, accessed November 18, 2012).

16 Convention on the Settlement of Investment Disputes between States and Nationals of Other States. (www.worldbank.org/icsid/, accessed November 18, 2012).

17 The ICSID Convention is a multilateral treaty formulated by the Executive Directors of the International Bank for Reconstruction and Development (the World Bank). It was opened for signature on March 18, 1965 and entered into force on October 14, 1966. For more information, see: official website of the International Centre for Settlement of Investment Disputes. (https://icsid.worldbank.org/ICSID/Index.jsp, accessed November 21, 2012).

18 With an increasing ICSID caseload, it has become ever more important for States to exercise their right to make designations to the ICSID Panels. To this end, the Centre continues to encourage States to name qualified candidates where nominations have expired or the Panels are otherwise incomplete. For more information, see: (2012 ISCID Annual Report, the access online, p. 17 and next).

\section{R E F E R E N C E S}

Agreement on the European Economic Area, (Official Journal L 001, 03/01/1994). Amerasinghe, Ch, F. (2008). Diplomatic Protection. Oxford: Oxford University Press.

Asian Agricultural Products Ltd. Versus Republic of Sri Lanca, arbitration award from June 27, 1990, § 21, quotation from: Jeżewski M. (2011). Międzynarodowe Prawo Inwestycyjne. Warszawa: C. H. Beck 2011, 98.

Bjorklund, A.K. (2008). National Treatment. In A. Reinisch (Ed.), Standards of Investment Protection (p. 29). Oxford: Oxford University Press.

Bos, M. (1984). A Methodology of International Law. Amsterdam-New YorkOxford, 105 and next.

Commission of the European Communities v. Italian Republic, Case C-174/04, http://eur-lex.europa.eu, accessed November 27, 2012.

Convention on the Settlement of Investment Disputes between States and Nationals of Other States from: www.worldbank.org/icsid/, accessed November 18, 2012 .

Cordero-Moss, G. (2008). Full Protection and Security. In A. Reinisch (Ed.), Standards of Investment Protection, (p. 132) Oxford: Oxford University Press.

Council Directive 88/361/EEC of 24 June 1988 for the implementation of Article 67 of the Treaty, (Official Journal L 178, 08/07/1988).

Dolzer, R., Schreuer, Ch. (2008). Principles of International Investment Law. Oxford: Oxford University Press, 178-179.

Reinisch A. (Ed.), Standards of Investment Protection Oxford: Oxford University Press, 122.

Draft Articles on Most-Favoured-Nation Clauses (ILC Draft), Yearbook of the International Law Commission, 1978, Volume II, Part Two, 21, 24 and next. 
(Eds.) Galicki, Z., Kamiński T. \& Myszona-Kostrzewa K. (2009). 40 lat minęło praktyka i perspektywy Konwencji Wiedeńskiej o prawie traktatów. Warszawa: Wydawnictwo Stowarzyszenia Absolwentów Wydziału Prawa i Administracji Uniwersytetu Warszawskiego.

(Eds.) Jennings, R., Watts A. (1992). Oppenheim's International Law, Volume I. (p. 1326), Harlow: Longman.

(Eds.) Muchlinski, P., Ortino F. \& Schreuer Ch. (2008). The Oxford Handbook of International Investment Law. Oxford: Oxford University Press.

Fair and Equitable Treatment, UNCTAD Series on Issues in International Investment Agreements II, New York and Geneva, 2012, 6-10.

Gaillard, E. (1999). Use of General Principles of International Law in International Long Term Contracts. International Business Lawyer, 27.

Walencik I., Gdy inwestor pozywa państwo - an interview with Abby Kohen Smutny from White \& Case Law Firm in Washington (2011, May 30). Rzeczpospolita, C4.

Gilas, J. (1998). Międzynarodowe Prawo Gospodarcze. Bydgoszcz: Branta.

Gizbert-Studnicki, T. (2011). Ujęcie instytucjonalne w teorii prawa. In J. Stelmach (Ed.), Studia z filozofii prawa (p. 123). Kraków: Wydawnictwo uniwersytetu Jagiellońskiego.

Góralczyk, W., Sawicki S. (2011). Prawo międzynarodowe publiczne w zarysie Warszawa: Lexis Nexis, 95, 96.

Graham, E., Krugman P. (1995). Foreign Direct Investment in the United States, International Investment under the1994 Energy Charter Treaty - Legal Negotiating and Policy Implications for International Investors within Western and CIS/Easter European Countries, Journal of Word Trade, 29, 5.

Grzybowski, T. (2012). Spory wokół reguły clara non sunt interpretanda. Państwo $i$ Prawo, 9, 46-60, especially 50.

Hallward-Dreimeier, M. (2003). Do Bilateral Investment Treaties Attract Foreign Investment? Only a Bit... but they can Bite. World Bank Research Paper, No. 3121, available at the official website of the World Bank at http://elibrary.worldbank.org/, accessed November 28, 2012.

International Court of Justice Statute, available at the official website of the International Court of Justice http://www.icj-cij.org/, retrieved November 01, 2012.

Jeżewski, M. (2011). Międzynarodowe Prawo Inwestycyjne. Warszawa: C. H. Beck 2011, 14-19, 141, 178-204, 205-218, 267-284, 284-296.

Kałduński, M. (2006). Klauzula największego uprzywilejowania. Toruń: TNOiK "Dom Organizatora", 177.

Kawaguchi, K. H. (2003). A Social Theory of International Law, International Relations as a Complex System. Leiden/Boston: Brill, 53.

The Vienna Convention on the Law of Treaties from the 23 May 1969 r., (United Nations Treaty Series, Volume 1155, p. 331). 
Maciej Perkowski, Ewelina Gruszewska

Lachs, M. (1992). Czy kryzys prawa międzynarodowego? Państwo i Prawo, 2, 1724.

Most-Favoured-Nation Treatment in International Investment Law, Organization for Economic Co-operation and Development's Working Papers on International Investment, 2004/2, 2.

Most-Favoured-Nation Treatment, UNCTAD Series on Issues in International Investment Agreements II, United Nations, New York and Geneva, 2010, 13$15,30-33$.

Moussis, N. (2011). Access to European Union Law, Economics, Policies. Rixensart: Euroconfidentiel, 85-116.

Piontek, E. (2009). Niektóre aspekty prawnomiędzynarodowe traktowania inwestorów zagranicznych w państwach przyjmujących. In A. Kozłowski \& B. Mielnik (Eds.), Odpowiedzialność międzynarodowa jako element międzynarodowego porzadku prawnego (p. 35 and next). Wrocław: Wydawnictwo Uniwersytetu Wrocławskiego.

Salacuse, J. W. (2010). The Law of Investment Treaties. Oxford: Oxford University Press.

Schill S. (2009). The Multilateralization on International Investment Law. Cambridge: Cambridge University Press.

Sornarajah, M. (2010). The International Law and Foreign Investment. Cambridge: Cambridge University Press, 10, 16.

Suez, Sociedad General de Aguas de Barcelona S.A. and Vivendi Universal S.A. versus Argentine Republic, Decision on the Argentine Republic's Request for a Continued Stay of Enforcement of the Award rendered on August 20, 2007, ICSID Case No. ARB/03/19, § 7.4.3, https://icsid.worldbank.org/, accessed 25 November, 2012.

The Concise Oxford Dictionary of Current English, Oxford 2011, from http://www.wordreference.com/definition/, retrieved November 25, 2012.

The International Centre for Settlement of Investment Disputes official website: https://icsid.worldbank.org/, retrieved November 25, 2012.

The treaty on the functioning of the European Union of 30 march 2010, (Official Journal of the European Union C 83/47).

The World Trade agreements available online on its official website, from http://www.wto.org/, retrieved November 28, 2012.

van Harten, G. (2007). Investment Treaty Arbitration and Public Law. Oxford:, Oxford University Press.

Vandevelde, K. J. (2010). Bilateral Investment Treaties, History, Policy and Interpretation. Oxford: Oxford University Press, 5, 6-10.

Wong, J. (2007). Umbrella Clauses In Bilateral Investment Treaties: Of Breaches of Contract, Treaty Violations and the Divide Between Developing and Developed Countries In Foreign Investment Disputes, 14 Geo. Mason L. Rev, 135, 135-177. 
Interpretation of Bilateral Treaties for the Promotion and Protection...

World Investment Report 2007, Transnational Corporations, Extractive Industries and Development, New York-Geneva 2007.

Wyrozumska, A. (2006). Umowy międzynarodowe. Teoria i praktyka. Warszawa: Wydawnictwo Prawo i Praktyka Gospodarcza.

Ziegler, A. R. (2008). Most-Favoured Nation Treatment. In A. Reinisch (Ed.), Standards of Investment Protection. (p. 60), Oxford: Oxford University Press.

2012 ISCID Annual Report, the access online, 17 and next. 